\title{
Vulvar Cancer pT2 TNM Finding v8
}

National Cancer Institute

\section{Source}

National Cancer Institute. Vulvar Cancer pT2 TNM Finding v8. NCI Thesaurus. Code C139604.

Vulvar cancer with tumor of any size with extension to adjacent perineal structures

(lower/distal third of the urethra, lower/distal third of the vagina, anal involvement). (from AJCC 8th Ed.) 